\title{
Pembatasan Sosial Berskala Besar (PSSB) saat Pandemi Covid-19 dan Dampaknya bagi Pasar Modal Indonesia
}

\author{
Ll. Irman Suhaedading a,1,* \\ ${ }^{a}$ Alumni Fakultas Ekonomika dan Bisnis, Universitas Gadjah Mada \\ ${ }^{1}$ lalu.irman.s@gmail.com* \\ * corresponding author
}

\section{ARTICLE INFO}

\section{Article History}

Received

Revised

Accepted

Keywords

Covid-19;

PSBB;

IHSG;

Saham

\section{ABSTRACT}

The research aims to see impact of Jakarta's Large Scale Social Distancing (PSBB) when the Covid-19 pandemic for capital market in Indonesia. The data used are Indonesia Composite Index (IHSG), a month before PSBB (2 March 2020 - 9 April 2020) and during PSBB (13 April 2020 - 5 June 2020). The research used Paired Sample T-Test, for comparing two samples data whether they are related or not.

The result: There is no significant different between stock price before PSBB and during PSBB. This point can be explained that investors have been anticipating the impact from Covid-19 pandemic. Likewise, Governor of Bank Indonesia said that PSSB in Jakarta will bring positive impact for money market, so that it makes positive sentiment for investors. Consequently, there is no significant impact for composite stock price.

\section{PENDAHULUAN}

Pandemi Covid-19 yang mewabah di seluruh dunia pada tahun 2020 muncul pertama kali pada akhir 2019 di Wuhan, Tiongkok. Awal mulanya, pemilik kios di pasar ikan dan hewan di Wuhan menderita pneumonia yang tidak diketahui sebabnya. Virus ini begitu cepat menyebar antar manusia dan kasus pertama Covid-19 di Indonesia, diumumkan pemerintah pada tanggal 2 Maret 2020.

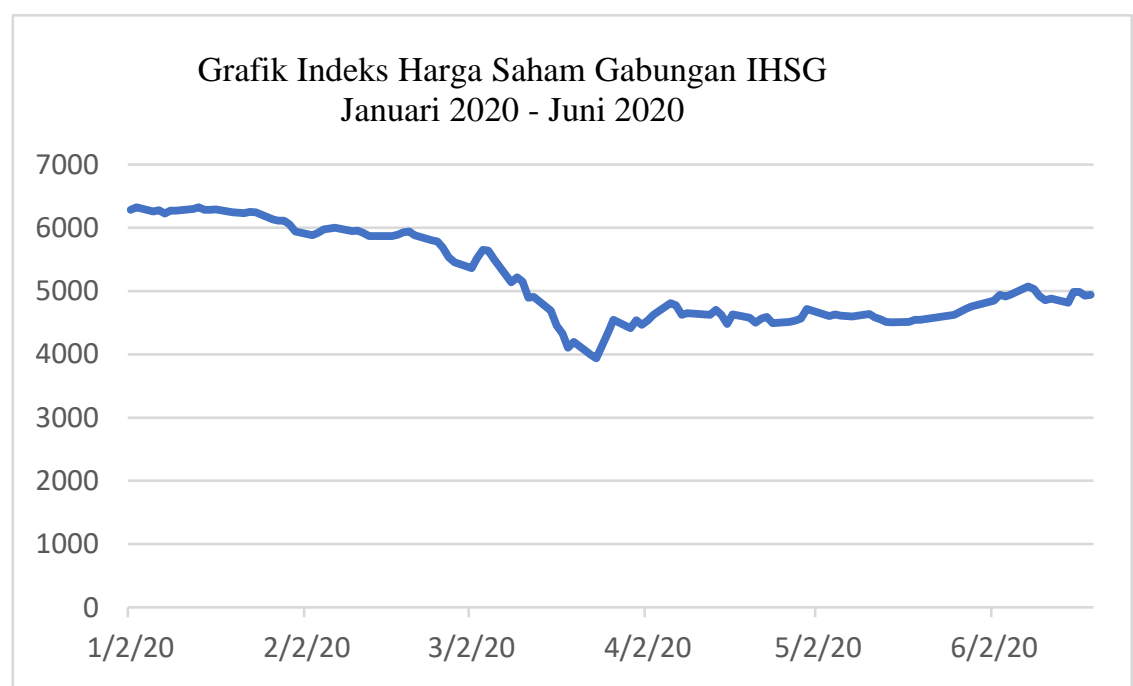

Gambar 1. Grafik Indeks Harga Saham Gabungan IHSG Januari 2020 - Juni 2020 Sumber: Data Sekunder Diolah, 2020

Mewabahnya pandemi Covid-19 ini ternyata sangat berdampak ke semua sektor. Termasuk sektor keuangan, dalam hal ini pasar saham Indonesia. Dapat dilihat pada Gambar 1.1 bahwa harga saham gabungan pada tanggal 2 Januari 2020 setelah libur akhir tahun sebesar 6.283,58. IHSG mengalami penurunan tajam pada tanggal 24 Maret 2020 sebesar 3.937,63. Kemudian naik tetapi berfluktuasi hingga tanggal 19 Juni 2020. Oleh karena itu, menarik untuk diteliti pergerakan harga saham sebulan sebelum penerapan Pembatasan Sosial Berskala Besar (PSBB) hingga saat PSBB di Jakarta diberlakukan. 
Dalam penelitian ini, pasar saham Indonesia cenderung menurun saat pandemi Covid-19 mewabah, terutama pada saat pemberlakuan PSBB di Jakarta. Oleh karena itu, diduga terdapat perbedaan siginifikan harga saham sebelum pemberlakuan PSBB dibandingkan saat PSBB dibelakukan. Jadi, peneliti merumuskan pertanyaan penelitian, yaitu: apakah terdapat perbedaan harga saham gabungan di Bursa Efek Indonesia sebelum PSBB dibandingkan saat PSBB DKI Jakarta diberlakukan?

\section{KAJIAN PUSTAKA}

\section{Pengertian Pasar Modal}

Menurut Tandelilin (2017), pasar modal adalah pasar untuk memperjualbelikan sekuritas yang umumnya memiliki umur lebih dari satu tahun, seperti saham, obligasi, dan reksadana. Jika pasar modal suatu negara lesu, maka akan memengaruhi kondisi pasar modal negara lain, atau disebut dengan Teori Contagion Effect. Dengan kata lain pasar modal yang besar akan memengaruhi pasar modal yang lebih kecil.

\section{Pengertian Saham}

Saham adalah surat berharga yang dimiliki oleh para investor, yang mana surat tersebut berfungsi sebagai status kepemilikan suatu perusahaan oleh investor. Menurut Tandelilin (2017), saham dapat dibedakan menjadi saham biasa dan saham preferen.

a. saham biasa merupakan suatu sertifikat yang menunjukkan kepemilikan suatu perusahaan. Misalnya seorang investor mempunyai 1 juta lembar saham biasa dari total 100 juta lembar saham biasa. Investor tersebut memiliki $1 \%$ perusahaan tempat ia berinvestasi;

b. Selanjutnya, saham preferen merupakan gabungan antara saham biasa dan obligasi. Saham preferen memiliki ciri yang sama dengan saham biasa, seperti kepemilikan, membayar dividen, dan tanpa jatuh tempo. Tetapi saham preferen juga mirip dengan obligasi karena menghasilkan pendapatan tetap dari dividennya.

\section{Indeks Harga Saham Gabungan (IHSG)}

IHSG merupakan salah satu indeks di Bursa Efek Indonesia (BEI). IHSG juga dikenal sebagai Indonesia Composite Index (ICI). IHSG diperkenalkan untuk pertama kalinya pada tanggal 1 April 1983.

\section{METODE PENELITIAN}

Penelitian ini menggunakan data kuantitatif dan sekunder. Data diperoleh dari https://id.investing.com. Data IHSG yang diambil mulai 2 Maret 2020 sampai dengan 9 April 2020 (sebulan sebelum PSBB DKI Jakarta diberlakukan) serta mulai tanggal 13 April 2020 sampai dengan 5 Juni 2020 (saat PSBB DKI Jakarta diberlakukan). Data yang digunakan adalah data harian yang selanjutnya diolah dengan menggunakan software Eviews, kemudian dianalisis. Penulis menggunakan analisis statistik untuk menjawab hipotesis yang telah dibangun. Desain yang digunakan dalam penelitian ini ditentukan untuk menguji apakah terdapat perbedaan harga saham gabungan di Bursa Efek Indonesia sebelum PSBB dibandingkan dengan saat PSBB di Jakarta diberlakukan.

Untuk menguji penelitian ini, digunakan uji Paired Sample T-Test. Uji ini digunakan untuk membandingkan dua sampel data apakah saling berhubungan atau tidak. Secara umum, persamaan yang digunakan untuk sampel berpasangan adalah sebagai berikut:

$$
t=\frac{\overline{x_{1}}-\overline{x_{2}}}{\sqrt{\frac{s_{1}^{2}}{n_{1}}+\frac{s_{2}^{2}}{n_{2}}-2 r\left(\frac{s_{1}}{n_{1}}\right)\left(\frac{s_{2}}{n_{2}}\right)}}
$$

dengan,

$\overline{x_{1}}=$ rata-rata sampel 1

$r=$ korelasi antar dua sampel

$\overline{x_{2}}=$ rata-rata sampel 2

$s_{1}=$ simpangan baku sampel 1

$s_{1}^{2}=$ varians sampel 1

$s_{2}^{2}=$ varians sampel 2

$s_{2}=$ simpangan baku sampel 2 
Berikut ini merupakan diagram alir penelitian

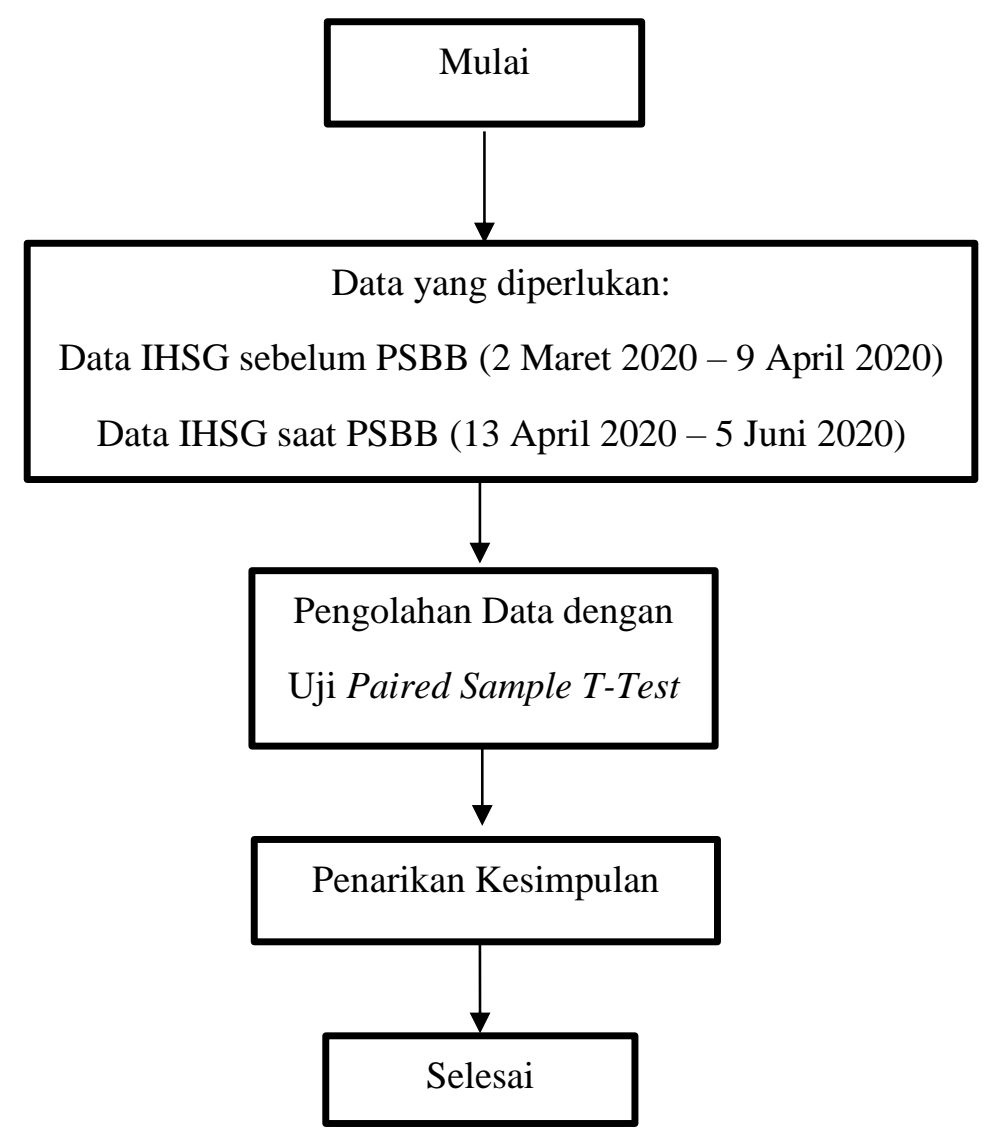

Gambar 2. Diagram Alir Penelitian

\section{HASIL dan PEMBAHASAN}

\section{Uji Normalitas}

Uji normalitas digunakan untuk mengetahui sebaran data dari sampel yang diambil. Uji normalitas dapat melihat apakah data berditribusi normal atau tidak. Ada dua uji pada uji normalitas yang biasa digunakan, yaitu uji Shapiro Wilk dan uji Kolmogorov Smirnov.

Tabel 1. Hasi Uji Normalitas

\begin{tabular}{|c|c|c|c|c|c|c|}
\hline & \multicolumn{3}{|c|}{ Kolmogorov-Smirnov } & \multicolumn{3}{|c|}{ Shapiro-Wilk } \\
\hline & Statistic & df & Sig. & Statistic & $\mathrm{df}$ & Sig. \\
\hline Sebelum_PSBB & .120 & 28 & $.200^{*}$ & .955 & 28 & .259 \\
\hline Saat_PSBB & .103 & 28 & $.200^{*}$ & .947 & 28 & .162 \\
\hline
\end{tabular}

Sumber: Data Diolah (2020)

Berdasarkan Tabel 1 dapat dilihat bahwa uji normalitas menggunakan Kolmogorov Smirnov, $p$ value variabel Sebelum_PSBB sebesar 0,2. Karena 0,2 > 0,05, sehingga dapat dikatakan bahwa data berdistribusi normal. Sedangkan uji normalitas menggunakan Shapiro Wilk, p-value variabel Sebelum_PSBB sebesar 0,259 > 0,05. Oleh karena itu, data berdistribusi normal.

Selanjutnya, pada variabel Saat_PSBB, uji normalitas menggunakan Kolmogorov Smirnov, diperoleh p-value sebesar 0,2>0,05. Artinya data berdistribusi normal. Begitu pula jika uji normalitas menggunakan Shapiro Wilk, p-value yang diperolah sebesar 0,162. Artinya data berdistribusi normal. Karena data kedua variabel berdistirbusi normal, maka asumsi normalitas dalam uji Paired Sample T-Test telah terpenuhi. 


\section{Uji Paired Sample T-Test}

Uji Paired Sample T-Test merupakan uji perbandingan terhadap dua data, yang dapat melihat apakah terdapat perbedaan rata-rata dua sampel (Sebelum_PSBB dan Saat_PSBB) yang saling berhubungan.

Tabel 2. Hasil Uji Paired Sample Statistics

\begin{tabular}{|ll|r|r|r|r|}
\hline & & \multicolumn{1}{|c|}{ Mean } & \multicolumn{1}{|c|}{ N } & Std. Deviation & Std. Error Mean \\
\hline Pair 1 & Sebelum_PSBB & $4.7505 E 3$ & 28 & 489.66651 & 92.53827 \\
& Saat_PSBB & $4.5831 \mathrm{E3}$ & 28 & 66.02366 & 12.47730 \\
\hline
\end{tabular}

Sumber: Data Diolah (2020)

Berdasarkan Tabel 2, dapat dilihat bahwa sampel yang diteliti adalah Sebelum_PSBB dan Saat_PSBB, dan jumlah sampel keduanya masing-masing 28 data. Pada variabel Sebelum_PSBB, mean yang diperoleh sebesar 4.750,5. Artinya, harga saham gabungan pada saat PSBB di Jakarta belum diberlakukan mempunyai harga rata-rata sebesar 4750,5. Sedangkan varabel Saat_PSBB diperoleh mean sebesar 4583,1. Artinya, harga saham gabungan pada saat PSBB di Jakarta telah diberlakukan mempunyai harga rata-rata sebesar 4.583,1. Untuk nilai std. deviation pada variabel Sebelum_PSBB adalah sebesar 489,66651. Sedangkan std. deviation pada variabel Saat_PSBB adalah sebesar 66,023.

Setelah diperoleh nilai mean pada hasil pengolahan data SPSS, dapat dilihat bahwa mean variabel Sebelum_PSBB lebih besar jika dibandingkan dengan mean variabel Saat_PSBB yaitu 4750,5 > 4583,1. Oleh karenat itu, berdasarkan perbandingan kedua nilai rata-rata tersebut, dapat disimpulkan bahwa terdapat penurunan harga saham gabungan ketika PSBB diberlakukan Artinya adalah ada perbedaaan ratarata harga saham antara Sebelum_PSBB dengan Saat_PSBB.

Pada Tabel 3, dapat dilihat bahwa korelasi antara kedua variabel baik Sebelum_PSBB dan Saat_PSBB sebesar -0,082, dengan $p$-value sebesar 0.677. Karena $p$-value $>0,05$, maka tidak terdapat korelasi antara variabel Sebelum_PSBB dengan variabel Saat_PSBB.

Tabel 3. Hasil Paired Samples Correlations

\begin{tabular}{|ll|r|r|r|}
\hline & \multicolumn{1}{|c|}{ N } & Correlation & \multicolumn{1}{c|}{ Sig. } \\
\hline Pair 1 Sebelum_PSBB \& Saat_PSBB & 28 & -.082 & .677 \\
\hline
\end{tabular}

Sumber: Data Diolah (2020)

Tabel 4. Hasil Uji Paired Samples T- Test

\begin{tabular}{|c|c|c|c|c|c|c|c|c|}
\hline & \multicolumn{5}{|c|}{ Paired Differences } & \multirow[b]{3}{*}{$\mathrm{t}$} & \multirow[b]{3}{*}{$\mathrm{df}$} & \multirow{3}{*}{$\begin{array}{l}\text { Sig. }(2- \\
\text { tailed) }\end{array}$} \\
\hline & \multirow[b]{2}{*}{ Mean } & \multirow{2}{*}{$\begin{array}{c}\text { Std. } \\
\text { Deviation }\end{array}$} & \multirow{2}{*}{$\begin{array}{l}\text { Std. Error } \\
\text { Mean }\end{array}$} & \multicolumn{2}{|c|}{$\begin{array}{l}95 \% \text { Confidence Interval of } \\
\text { the Difference }\end{array}$} & & & \\
\hline & & & & Lower & Upper & & & \\
\hline $\begin{array}{cl}\text { Pair } 1 & \text { Sebelum_PSBB - } \\
& \text { Saat_PSBB }\end{array}$ & $1.67336 \mathrm{E} 2$ & 499.45872 & 94.38883 & -26.33416 & 361.00559 & 1.773 & 27 & .088 \\
\hline
\end{tabular}

Sumber: Data Diolah (2020)

Selanjutnya, Tabel 4 menunjukkan hasi uji Paired Sample T-Test. Dapat dilihat bahwa $p$-value yang diperoleh sebesar 0,088. Karena 0,088 >0,05, maka tidak terdapat perbedaan signifikan antara harga saham sebelum PSBB DKI Jakarta diberlakukan dan saat berlangsungnya PSBB. Pada Tabel 4 juga diperoleh perbedaan mean harga saham gabungan sebelum dan saat PSBB DKI Jakarta sebesar 167,336. Karena mean positif, maka harga saham sebelum PSBB Jakarta mempunyai nilai rata-rata lebih besar jika dibandingkan dengan harga saham gabungan saat berlakunya PSBB.

Walaupun pada hasil uji Paired Samples T-Test menunjukkan mean yang positif, nyatanya tidak terdapat perbedaan signifikan antara harga saham sebelum PSBB DKI Jakarta diberlakukan dengan saat berlangsungnya PSBB. Hal ini dapat dijelaskan sebagai berikut. Pada tanggal 2 Januari 2020 setelah libur akhir tahun, harga saham gabungan berada pada level 6.283,58. Kemudian IHSG mengalami penurunan tajam pada tanggal 24 Maret 2020 sebesar 3.937,63. Artinya adalah sepanjang bulan Januari sampai dengan Maret 2020, IHSG mengalami penurunan sebesar 37,33\%. Hal ini disebabkan karena isu-isu global 
seperti pandemi Covid-19 yang mewabah di berbagai negara. Sehingga memunculkan sentimen negatif serta aksi profit taking.

Kemudian, sebulan sebelum bergulirnya isu PSBB DKI Jakarta (2 Maret 2020 sampai dengan 9 April 2020), investor sudah mulai mengantisipasi dampak yang mungkin ditimbulkan oleh pandemi Covid-19. Akibatnya, saat PSBB DKI diberlakukan (13 April - 5 Juni 2020), tidak terdapat dampak yang signifikan pada harga saham gabungan, yang berakibat pada tidak ada gejolak yang berarti pada harga saham gabungan sepanjang PSBB diberlakukan di Jakarta.

Hal ini sesuai dengan pernyataan Gubernur Bank Indonesia, Perry Warjiyo, yang mengatakan bahwa PSBB yang diterapkan di Jakarta justru akan membawa dampak positif bagi pasar keuangan. Perry mengatakan bahwa PSBB merupakan salah satu langkah yang diambil pemerintah untuk mencegah penyebaran virus, sehingga PSBB ini membuat sentimen positif di kalangan investor. Akibat membaiknya sentimen investor, maka berdampak pula pada penguatan nilai tukar rupiah

Selanjutnya, kondisi risiko global mulai membaik berdasarkan Volatility Index (VIX) yang sempat menyentuh level 18,8. Berbeda jauh saat bulan Maret 2020 yang menyentuh hingga level 82.

\section{KESIMPULAN}

Pada penelitian ini diperoleh hasil dari uji Paired Sample T-Test dari harga saham gabungan, sebelum diberlakukan PSBB DKI Jakarta dan saat PSBB DKI Jakarta berlangsung, yang menunjukkan bahwa tidak terdapat perbedaan signifikan antara harga saham sebelum PSBB DKI Jakarta diberlakukan dan saat berlangsungnya PSBB.

Hal ini disebabkan karena investor mulai mengantisipasi dampak yang ditimbulkan oleh pandemi Covid19 sejak bergulirnya isu PSBB DKI Jakarta. Akibatnya, tidak ada gejolak yang berarti pada harga saham gabungan sepanjang PSBB diberlakukan di Jakarta.

\section{DAFTAR PUSTAKA}

[1]. Corbet, S., Larkin, C., Lucey, B. (2020). The Contagion Effects of The Covid-19 Pandemic: Evidence from Gold and Cryptocurrencies. Finance Research Letter, Elsevier.

[2]. Sharif, A., Aloui, C., Yarovaya, L. (2020). Covid-19 Pandemic, Oil Prices, Stock Market, Geopolitical Risk and Policy Uncertainty Nexus in The US Economy: Fresh Evidence from The Wavelet-Based Approach. International Review of Financial Analysisi 70 (2020) 101496.

[3]. Tandelilin, E. (2017). Pasar Modal, Manajemen Portofolio dan Investasi. Kanisius, Yogyakarta.

[4]. Ulya, F. N. (2020). Gubernur BI: PSBB Bawa Sentimen Positif untuk Investor. Tersedia di https://money.kompas.com/read/2020/04/10/080800026/gubernur-bi--psbb-bawa-sentimen-positif-untukinvestor?page=all\#page2, diakses pada 16 Juli 2020.

[5]. Zhang, D., Hu, M., Ji, Q. (2020). Financial Market Under The Global Pandemic of Covid-19. Finance Research Letter, Elsevier. 